\title{
Chest symptoms and farmer's lung: a community survey
}

\author{
D. C. MORGAN, J. T. SMYTH, R. W. LISTER, and R. J. PETHYBRIDGE \\ Hawkmoor Hospital, Bovey Tracey, Devon, and Institute of Biometry and \\ Community Medicine, University of Exeter
}

\begin{abstract}
Morgan, D. C., Smyth, J. T., Lister, R. W., and Pethybridge, R. J. (1973). British Journal of Industrial Medicine, 30, 259-265. Chest symptoms and farmer's lung: a community survey. Farmer's lung is one of the commonest causes of extrinsic allergic alveolitis, but there have been few studies of representative samples of farmers. A survey was carried out in Devon among 91 farmers and their families in order to estimate the prevalence of respiratory symptoms and of positive precipitin reactions to thermophilic fungi. Answers to a questionnaire about respiratory symptoms and smoking habits revealed among the men a prevalence of symptoms comparable with that found in other surveys of agricultural populations in the United Kingdom but with a lower proportion of smokers. A positive answer to a question about attacks of breathlessness associated with fever or shivering appeared to differentiate people suffering from farmer's lung. Twenty-three per cent of the population had precipitins to Micropolyspora faeni and two of these individuals also had precipitins to other fungi. There were statistically significant differences in the proportions of positive precipitin tests found in smokers, ex-smokers, and non-smokers. Six known cases of farmer's lung were included in the sample and all had positive precipitins.
\end{abstract}

Farmer's lung is an occupational disease due to inhalation of dust of mouldy hay or of other mouldy vegetable matter. Since the first description of farmer's lung in the United Kingdom (Campbell, 1932) features of the disorder have been more clearly defined. Fuller (1953) summarized its clinical course and Pepys et al. (1963) and Pepys, Longbottom, and Jenkins (1964) reported the association with specific antibody response to thermophilic actinomycetes and particularly Micropolyspora faeni. The relation between the acute and chronic phase was clarified by Hapke, Seal, and Thomas (1968), who noted that disability due to farmer's lung might have an insidious onset and that co-workers of farmer's lung patients had a higher prevalence of precipitins against $M$. faeni than the general population. Wenzel, Gray, and Emanuel (1970) have shown that a number of cases of ill-defined chest disease in farmers were accompanied by positive serological tests for M. faeni. Boyd (1971) reported a survey which included a random sample of $\mathbf{5 0}$ farmers without respiratory symptoms and found none with a positive gel-diffusion test. He contrasted his findings with those of Pepys and Jenkins (1965), who reported a prevalence of $18 \%$ of precipitating antibodies in healthy farmers. Grant et al. (1972) carried out a pilot survey in order to determine the prevalence of farmer's lung in Scotland but investigated extensively only those persons selected on the basis of compatible symptoms and occupational exposure.

As Fuller (1953) reported, the disease has been recognized for some years in Devon, and in the winter of 1969-70, co-workers of 10 known cases of farmer's lung in one area of Devon were investigated. There were 17 co-workers and five of these had positive precipitins against $M$. faeni but no obvious disability. As the information concerning farmer's lung and the presence of associated precipitins among groups of farmers is limited and conflicting, a population survey was planned in 1970 with three objectives:

(1) to determine the prevalence of chest symptoms 
occurring among a population of farmers, their families, and farmworkers living and working in Devon;

(2) to determine the prevalence of precipitin reactions to antigens associated with farmer's lung in sera obtained from the study population; and

(3) to determine the relationship between chest symptoms, chest illness, and serological reactions within the study population.

\section{Material and methods}

From a total of $\mathbf{3 0 0}$ farmers on the lists of three general practitioners, 92 were randomly selected and invited to take part in the investigation. Ninety-one accepted and they, together with members of their families aged 15 to 65 years, were investigated by one observer (R.W.L.) during the winter of 1970-71, making a total of 188 persons living or working on the farms. Family members living on the farm but having a full-time occupation outside the farm were excluded. From the families who cooperated, two people refused to have blood taken for examination.

The investigation included questions derived from the Medical Research Council questionnaire on respiratory symptoms (Medical Research Council, 1966); modifications had been made to elicit the presence of attacks of breathlessness associated with fever or shivering, a history of allergy, and past illnesses other than chest illnesses. A more comprehensive occupational history was also included. Blood samples were taken for serological testing by the Public Health Laboratory Service. After the survey had been completed the practice records of people with positive serological findings were examined in consultation with the general practitioner and the symptoms recorded on the questionnaire were compared with the practice record. There was good agreement in most cases.

\section{Results}

The overall prevalence of phlegm production on most days during at least three months of the year, taken as a definition of bronchitis (Fletcher, Elmes, Fairbairn, and Wood, 1959), was $9 \%$ in men and under $2 \%$ in women. Table 1 a shows that the prevalence in men was higher in those over 45 years of age.

Positive serological reactions to $M$. faeni were found in $29 \%$ of the men and in $10 \%$ of the women, the difference being significant at the $5 \%$ level (Table 1b). Only one man had a positive reaction to Thermoactinomyces vulgaris and one man to Aspergillus fumigatus. Both men also had positive reactions to $M$. faeni. There appeared to be an increase in the proportions of those with positive serology with increasing age, mainly in non-smokers and ex-smokers but not in smokers. The sample was not large enough for significant differences to be detected.

The proportions of positive serological results found in the smokers, ex-smokers, and non-smokers
TABLE 1

(a) Prevalence of Phlegm Production on Most Days for at LEAST THREe MONTHS PER YeAR

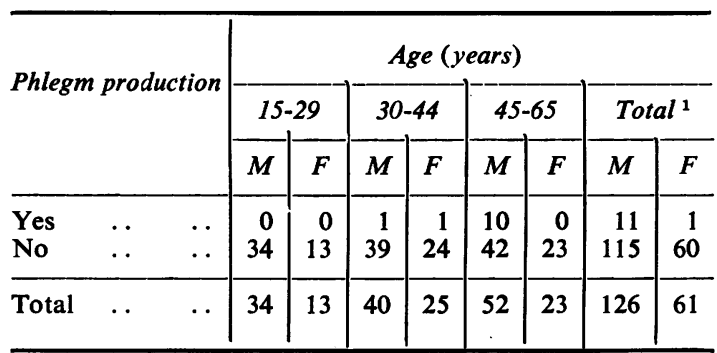

'One man of unknown age excluded

(b) Prevalence of Positive Serological RESULTS

\begin{tabular}{|c|c|c|c|c|c|c|c|c|c|}
\hline \multirow{3}{*}{ Serology } & & \multicolumn{8}{|c|}{ Age (years) } \\
\hline & & \multicolumn{2}{|c|}{$15-29$} & \multicolumn{2}{|c|}{$30-44$} & \multicolumn{2}{|c|}{$45-65$} & \multicolumn{2}{|c|}{ Total $^{1}$} \\
\hline & & $M$ & $F$ & $M$ & $F$ & $M$ & $F$ & $M$ & $F$ \\
\hline $\begin{array}{l}\text { Positive } \\
\text { Negative }\end{array}$ & $\begin{array}{l}\cdots \\
\cdots\end{array}$ & $\begin{array}{r}7 \\
25\end{array}$ & $\begin{array}{r}1 \\
11\end{array}$ & $\begin{array}{l}13 \\
27\end{array}$ & $\begin{array}{r}2 \\
22\end{array}$ & $\begin{array}{l}15 \\
37\end{array}$ & $\begin{array}{r}3 \\
20\end{array}$ & $\begin{array}{l}35 \\
89\end{array}$ & $\begin{array}{r}6 \\
53\end{array}$ \\
\hline Total & & 32 & 12 & 40 & 24 & 52 & 23 & 124 & 59 \\
\hline
\end{tabular}

${ }^{1}$ One man of unknown age and two men and two women with sera not tested excluded from total

showed significant differences at between the $5 \%$ and $10 \%$ levels. The highest proportion was found in non-smokers, to whom the ex-smokers were similar in this respect (Table 2).

The relation between some of the symptoms, smoking habits, and serological results is given in Tables $3 \mathrm{a}$ (men) and $3 \mathrm{~b}$ (women). Attacks of breath-

TABLE 2

Relation of Serological Results to Sex aNd SMOKING Habits

\begin{tabular}{|c|c|c|c|c|c|c|}
\hline $\begin{array}{c}\text { Results } \\
\text { from sera }\end{array}$ & & Sex & Smokers & $\begin{array}{c}\text { Ex- } \\
\text { smokers }\end{array}$ & $\begin{array}{c}\text { Non- } \\
\text { smokers }\end{array}$ & All \\
\hline Negative & . & $\begin{array}{l}\mathbf{M} \\
\mathbf{F}\end{array}$ & $\begin{array}{r}38 \\
7\end{array}$ & $\begin{array}{r}25 \\
7\end{array}$ & $\begin{array}{l}26 \\
39\end{array}$ & $\begin{array}{l}89 \\
53\end{array}$ \\
\hline Positive & .. & $\begin{array}{l}\mathbf{M} \\
\mathbf{F}\end{array}$ & $\begin{array}{l}4,4 \\
0,0\end{array}$ & $\begin{array}{l}4,8 \\
0,0\end{array}$ & $\begin{array}{l}8,8 \\
3,3\end{array}$ & $\begin{array}{r}36 \\
6\end{array}$ \\
\hline Total & .. & .. & 53 & 44 & 87 & $184^{1}$ \\
\hline
\end{tabular}

${ }^{1}$ Not tested-two men, two women (excluded from total) The positives are recorded as $n_{1}, n_{2}$, where $n_{1}$ is the number of weak positives and $n_{2}$ the number of moderate and strong positives. 
TABLE 3a

Respiratory Symptoms, Past Illness, Smoking Habits, and Serological Results in Men

\begin{tabular}{|c|c|c|c|c|c|c|c|c|c|c|c|c|c|}
\hline \multicolumn{8}{|c|}{ Question } & \multirow[b]{2}{*}{$\begin{array}{l}\text { No } \\
\text { Yes }\end{array}$} & \multirow{2}{*}{$\begin{array}{c}\begin{array}{c}\text { Serological } \\
\text { results }\end{array} \\
-\mathrm{ve} \\
+\mathrm{ve} \\
-\mathrm{ve} \\
+\mathrm{ve}\end{array}$} & \multirow{2}{*}{$\begin{array}{c}\text { Smokers } \\
32 \\
3,4 \\
6 \\
1,0\end{array}$} & \multirow{2}{*}{$\begin{array}{c}\begin{array}{c}\text { Ex- } \\
\text { smoker }\end{array} \\
22 \\
4,7 \\
3 \\
0,1\end{array}$} & \multirow{2}{*}{$\begin{array}{c}\begin{array}{c}\text { Non- } \\
\text { smokers }\end{array} \\
26 \\
8,8 \\
0 \\
0\end{array}$} & \multirow{2}{*}{$\begin{array}{c}\text { Total } \\
80 \\
34 \\
9 \\
2\end{array}$} \\
\hline Persistent phlegm & $\cdots$ & $\cdots$ & . & . & . & . & . & & & & & & \\
\hline Attacks of breathlessn & less & $\cdots$ & . & . & . & . & . & $\begin{array}{l}\text { No } \\
\text { Yes }\end{array}$ & $\begin{array}{l}\text { - ve } \\
\text { +ve } \\
\text { - ve } \\
\text { +ve }\end{array}$ & $\begin{array}{c}32 \\
3,4 \\
6 \\
1,0\end{array}$ & $\begin{array}{c}19 \\
3,5 \\
6 \\
1,3\end{array}$ & $\begin{array}{c}23 \\
6,7 \\
3 \\
2,1\end{array}$ & $\begin{array}{r}74 \\
28 \\
15 \\
8\end{array}$ \\
\hline \multicolumn{5}{|c|}{ Attacks of breathlessness, fever or shivering } & . & . & $\cdots$ & $\begin{array}{l}\text { No } \\
\text { Yes }\end{array}$ & $\begin{array}{l}\text {-ve } \\
+ \text { ve } \\
\text { - ve } \\
\text { +ve }\end{array}$ & $\begin{array}{c}4 \\
1,0 \\
2 \\
0,0\end{array}$ & $\begin{array}{c}4 \\
1,0 \\
2 \\
0,3\end{array}$ & $\begin{array}{c}2 \\
1,1 \\
1 \\
1,0\end{array}$ & $\begin{array}{r}10 \\
4 \\
5 \\
4\end{array}$ \\
\hline \multicolumn{4}{|c|}{ Shortness of breath hurrying on level } & .. & . & . & . & $\begin{array}{l}\text { No } \\
\text { Yes }\end{array}$ & $\begin{array}{l}\text { - ve } \\
\text { +ve } \\
\text { - ve } \\
\text { +ve }\end{array}$ & $\begin{array}{c}29 \\
3,4 \\
9 \\
1,0\end{array}$ & $\begin{array}{c}19 \\
4,5 \\
6 \\
0,3\end{array}$ & $\begin{array}{c}26 \\
7,8 \\
0 \\
1,0\end{array}$ & $\begin{array}{r}74 \\
31 \\
15 \\
5\end{array}$ \\
\hline Weather affects chest & . & . & . & . & . & . & . & $\begin{array}{l}\text { No } \\
\text { Yes }\end{array}$ & $\begin{array}{l}\text { - ve } \\
\text { +ve } \\
\text { - ve } \\
\text { +ve }\end{array}$ & $\begin{array}{c}34 \\
3,4 \\
4 \\
1,0\end{array}$ & $\begin{array}{c}24 \\
4,5 \\
1 \\
0,3\end{array}$ & $\begin{array}{c}25 \\
7,8 \\
1 \\
1,0\end{array}$ & $\begin{array}{r}83 \\
31 \\
6 \\
5\end{array}$ \\
\hline Chest illness within pa & ast 3 & ears & . & . & . & . & . & $\begin{array}{l}\text { No } \\
\text { Yes }\end{array}$ & $\begin{array}{l}\text { - ve } \\
\text { +ve } \\
\text { - ve } \\
\text { +ve }\end{array}$ & $\begin{array}{c}34 \\
4,3 \\
4 \\
0,1\end{array}$ & $\begin{array}{c}23 \\
4,5 \\
2 \\
0,3\end{array}$ & $\begin{array}{c}25 \\
8,7 \\
1 \\
0,1\end{array}$ & $\begin{array}{r}82 \\
31 \\
7 \\
5\end{array}$ \\
\hline Asthma .. & . & . & $\cdots$ & . & . & . & . & $\begin{array}{l}\text { No } \\
\text { Yes }\end{array}$ & $\begin{array}{l}\text { - ve } \\
\text { +ve } \\
\text { - ve } \\
\text { +ve }\end{array}$ & $\begin{array}{c}35 \\
4,4 \\
3 \\
0,0\end{array}$ & $\begin{array}{c}24 \\
4,7 \\
1 \\
0,1\end{array}$ & $\begin{array}{c}25 \\
7,8 \\
1 \\
1,0\end{array}$ & $\begin{array}{r}84 \\
34 \\
5 \\
2\end{array}$ \\
\hline Hay fever & .. & $\cdots$ & $\cdots$ & . & . & . & . & $\begin{array}{l}\text { No } \\
\text { Yes }\end{array}$ & $\begin{array}{l}\text { - ve } \\
\text { +ve } \\
\text { - ve } \\
\text { +ve }\end{array}$ & $\begin{array}{c}33 \\
4,4 \\
5 \\
0,0\end{array}$ & $\begin{array}{c}23 \\
2,7 \\
2 \\
1,1\end{array}$ & $\begin{array}{c}21 \\
7,8 \\
5 \\
1,0\end{array}$ & $\begin{array}{r}77 \\
32 \\
12 \\
3\end{array}$ \\
\hline Serious illness of any 1 & kind & the & & $\cdots$ & . & . & . & $\begin{array}{l}\text { No } \\
\text { Yes }\end{array}$ & $\begin{array}{l}\text { - ve } \\
\text { +ve } \\
\text { - ve } \\
\text { +ve }\end{array}$ & $\begin{array}{c}33 \\
4,2 \\
5 \\
0,2\end{array}$ & $\begin{array}{c}22 \\
3,5 \\
3 \\
1,3\end{array}$ & $\begin{array}{c}22 \\
6,6 \\
4 \\
2,2\end{array}$ & $\begin{array}{l}77 \\
26 \\
12 \\
10\end{array}$ \\
\hline
\end{tabular}

Positive serological results recorded as $n_{1}$ and $n_{2}$, where $n_{1}$ is the number of weak positive results and $n_{2}$ the number of moderate and strong positive results

lessness were reported in 23 of the 125 men (18\%) and in 6 of the 59 women (10\%). For men, 8 out of $23(35 \%)$ who reported attacks of breathlessness had positive serological results compared with 28 of $102(28 \%)$ who did not report any such attacks. Nine of these men had attacks of breathlessness accompanied by fever and shivering; of these, four had positive serological results. Of the remaining 14 men who had attacks of breathlessness but no fever or shivering, four had positive results. Eleven men had chest symptoms affected by weather and 12 men had chest illnesses within the past three years leading to at least one week off work. Twenty-two men had had a past serious illness of any kind, and 10 of these had positive precipitins. The diagnosis of the previous illness was of pneumonia, pleurisy or farmer's lung in 10 cases, of whom six had precipitins present.

The survey included six persons known to their practitioner to suffer or to have suffered from farmer's lung but four of them did not report this condition as a 'past serious illness of any kind'. The findings in the six cases which included five men and one woman are given in Table 4. Five reported attacks of breathlessness associated with fever and 
TABLE $3 b$

Respiratory Symptoms, Past Illness, Smoking Habits, and Serological Results in Women

\begin{tabular}{|c|c|c|c|c|c|c|c|c|c|c|c|c|c|}
\hline \multicolumn{8}{|c|}{ Question } & \multirow[b]{2}{*}{$\begin{array}{l}\text { No } \\
\text { Yes }\end{array}$} & \multirow{2}{*}{$\begin{array}{c}\begin{array}{c}\text { Serological } \\
\text { results }\end{array} \\
\text {-ve } \\
\text { +ve } \\
\text { - ve } \\
\text { +ve }\end{array}$} & \multirow{2}{*}{$\begin{array}{c}\text { Smokers } \\
7 \\
0,0 \\
0 \\
0,0\end{array}$} & \multirow{2}{*}{$\begin{array}{c}\begin{array}{c}\text { Ex- } \\
\text { smokers }\end{array} \\
7 \\
0,0 \\
0 \\
0,0\end{array}$} & \multirow{2}{*}{$\begin{array}{c}\begin{array}{c}\text { Non- } \\
\text { smokers }\end{array} \\
39 \\
3,2 \\
0 \\
0,1\end{array}$} & \multirow{2}{*}{$\begin{array}{r}\text { Total } \\
53 \\
5 \\
0 \\
1\end{array}$} \\
\hline Persistent phlegm & .. & .. & . & . & . & . & . & & & & & & \\
\hline Attacks of breathlessn & ess & .. & . & . & . & . & . & $\begin{array}{l}\text { No } \\
\text { Yes }\end{array}$ & $\begin{array}{l}\text {-ve } \\
+ \text { ve } \\
\text { - ve } \\
+ \text { ve }\end{array}$ & $\begin{array}{c}6 \\
0,0 \\
1 \\
0,0\end{array}$ & $\begin{array}{c}7 \\
0,0 \\
0 \\
0,0\end{array}$ & $\begin{array}{c}35 \\
3,2 \\
4 \\
0,1\end{array}$ & $\begin{array}{r}48 \\
5 \\
5 \\
1\end{array}$ \\
\hline \multicolumn{5}{|c|}{ Attacks of breathlessness, fever or shivering } & . & . & . & $\begin{array}{l}\text { No } \\
\text { Yes }\end{array}$ & $\begin{array}{l}\text {-ve } \\
+ \text { ve } \\
\text {-ve } \\
+ \text { ve }\end{array}$ & $\begin{array}{c}1 \\
0,0 \\
0 \\
0,0\end{array}$ & $\begin{array}{c}0 \\
0 \\
0 \\
0,0\end{array}$ & $\begin{array}{c}4 \\
0,0 \\
0 \\
0,1\end{array}$ & $\begin{array}{l}5 \\
0 \\
0 \\
1\end{array}$ \\
\hline \multicolumn{4}{|c|}{ Shortness of breath hurrying on level } & $\cdots$ & . & . & . & $\begin{array}{l}\text { No } \\
\text { Yes }\end{array}$ & $\begin{array}{l}\text {-ve } \\
+ \text { ve } \\
\text { - ve } \\
+ \text { ve }\end{array}$ & $\begin{array}{c}5 \\
0,0 \\
2 \\
0,0\end{array}$ & $\begin{array}{r}7 \\
0,0 \\
0 \\
0,0\end{array}$ & $\begin{array}{c}36 \\
3,2 \\
3 \\
0,1\end{array}$ & $\begin{array}{r}48 \\
5 \\
5 \\
1\end{array}$ \\
\hline Weather affects chest & . & . & . & . & . & . & . & $\begin{array}{l}\text { No } \\
\text { Yes }\end{array}$ & $\begin{array}{l}\text { - ve } \\
\text { +ve } \\
\text { - ve } \\
\text { +ve }\end{array}$ & $\begin{array}{c}7 \\
0,0 \\
0 \\
0,0\end{array}$ & $\begin{array}{c}7 \\
0,0 \\
0 \\
0,0\end{array}$ & $\begin{array}{c}39 \\
3,2 \\
0 \\
0,1\end{array}$ & $\begin{array}{r}53 \\
5 \\
0 \\
1\end{array}$ \\
\hline Chest illness within pa & ast 3 & ars & . & . & . & . & .. & $\begin{array}{l}\text { No } \\
\text { Yes }\end{array}$ & $\begin{array}{l}\text { - ve } \\
+ \text { ve } \\
\text { - ve } \\
+ \text { ve }\end{array}$ & $\begin{array}{c}7 \\
0,0 \\
0 \\
0,0\end{array}$ & $\begin{array}{c}6 \\
0,0 \\
1 \\
0,0\end{array}$ & $\begin{array}{c}38 \\
3,2 \\
1 \\
0,1\end{array}$ & $\begin{array}{r}51 \\
5 \\
2 \\
1\end{array}$ \\
\hline Asthma .. & . & .. & . & . & . & . & .. & $\begin{array}{l}\text { No } \\
\text { Yes }\end{array}$ & $\begin{array}{l}\text { - ve } \\
\text { +ve } \\
\text { - ve } \\
\text { +ve }\end{array}$ & $\begin{array}{c}7 \\
0,0 \\
0 \\
0,0\end{array}$ & $\begin{array}{c}7 \\
0,0 \\
0 \\
0,0\end{array}$ & $\begin{array}{c}39 \\
3,3 \\
0 \\
0,0\end{array}$ & $\begin{array}{r}53 \\
6 \\
0 \\
0\end{array}$ \\
\hline Hay fever & . & . & . & . & . & .. & . & $\begin{array}{l}\text { No } \\
\text { Yes }\end{array}$ & $\begin{array}{l}\text { - ve } \\
\text { +ve } \\
\text { - ve } \\
\text { +ve }\end{array}$ & $\begin{array}{c}5 \\
0,0 \\
2 \\
0,0\end{array}$ & $\begin{array}{c}7 \\
0,0 \\
0 \\
0,0\end{array}$ & $\begin{array}{c}37 \\
3,3 \\
2 \\
0,0\end{array}$ & $\begin{array}{r}49 \\
6 \\
4 \\
0\end{array}$ \\
\hline Serious illness of any 1 & kind & the & & $\cdots$ & . & .. & . & $\begin{array}{l}\text { No } \\
\text { Yes }\end{array}$ & $\begin{array}{l}\text { - ve } \\
\text { +ve } \\
\text {-ve } \\
\text { +ve }\end{array}$ & $\begin{array}{c}5 \\
0,0 \\
2 \\
0,0\end{array}$ & $\begin{array}{c}6 \\
0,0 \\
1 \\
0,0\end{array}$ & $\begin{array}{c}37 \\
3,2 \\
2 \\
0,1\end{array}$ & $\begin{array}{r}48 \\
5 \\
5 \\
1\end{array}$ \\
\hline
\end{tabular}

Positive serological results recorded as $n_{1}$ and $n_{2}$, where $n_{1}$ is the number of weak positive results and $n_{2}$ the number of moderate and strong positive results

shivering and four reported shortness of breath when hurrying on the level. All six were farming actively and wore protective masks of some kind at some period during their work. All six had positive precipitin tests. One other farmer gave a history of severe rhinitis and had precipitins present.

Subjects with precipitins were all associated with farms rearing cattle and all were exposed to dust from hay but there were few subjects without such exposure. Other exposure in relation to positive precipitin tests is shown in Table 5 , which also indicates those people who usually wore a mask at any time during the course of their work.

There were only six positive serological results obtained from women and it was therefore not possible to show for them any particular association between the serological findings and symptoms.

\section{Discussion}

The lists of three general practitioners were used as the sampling frame for the investigation. This 
TABLE 4

Selected Answers to Questionnaire by 6 Cases of Previously Diagnosed Farmer's Lung

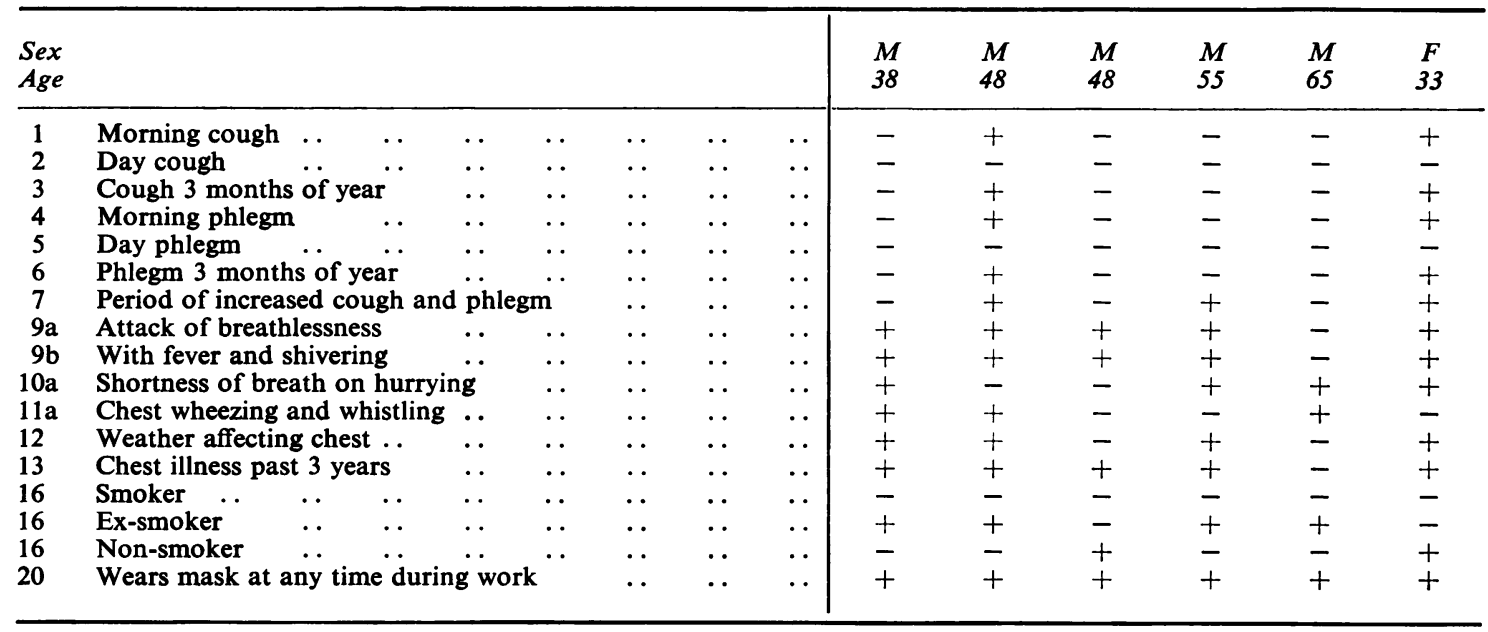

+ affirmative answer; - negative answer

allowed each of the practitioners to write individually to his patients inviting their cooperation, and also facilitated the association of past medical histories with information obtained from the survey. It was considered that the approach from the general practitioners to their patients had much to do with the good response rate. Occupations were not always shown on the records, and the doctors and their staft gave much assistance in filling in the gaps and editing the final lists. Although the method was timeconsuming and other sources from which a sample could be derived were available, it was considered that in the circumstances of the study, the disadvantages were outweighed by the goodwill created and by the access to the past medical history of the participants in the survey.

The prevalence of symptoms in agricultural communities has been measured by Higgins (1957) in Wales and by Higgins and Cochran (1958) in Scotland. The general pattern of respiratory symptoms in the two samples was similar, persistent phlegm production being found in $26 \%$ and $20 \%$ of the men and in $18 \%$ and $11 \%$ of the women aged 55 to 64 years. In Devon, 10 out of 52 men (19\%) aged 45 years and over had persistent phlegm but none of the 23 women of the same age group. Only 2 out of 112 persons below the age of 45 admitted to persistent phlegm. Smoking habits as reported in the Welsh and Scottish surveys were similar. For example, in Scotland 6 out of 94 men $(6 \%)$ were non-smokers and 64 out of 92 women $(70 \%)$. In Devon, 44 out of 127 men (35\%) and 47 out of 61 women $(77 \%)$ were non-smokers. Forty-six men $(36 \%)$ and seven women $(11 \%)$ were presently smoking. The Tobacco Research Council (1972) reported that of male farmers, foresters, and fishermen, $33 \%$ were cigarette smokers in 1971 although the proportion was only given with confidence limits of $\pm 10 \cdot 1 \%$ and over.

Differences in the prevalence of respiratory symptoms between agricultural populations have been discussed by Olsen and Gilson (1960). They suggested that these differences might be explained in part by differences in smoking habits. Smoking appears to be less frequent among farmers in Devon than previously reported in the agricultural communities of Wales and Scotland. While the lower prevalence of symptoms and lower proportion of smokers among the Devon women is in accord with this hypothesis, the same relationship does not apply to the men. For them, a large reduction in the proportion of smokers is not associated with a corresponding decrease in symptoms.

The surveys in Wales and Scotland preceded that in Devon by some years so that comparisons of levels of amounts smoked may be confused by secular trends.

The majority of those with precipitins were employed full time in farm work and all had been exposed to dust from hay. There was no significant association between positive reactions and additional exposure to dust from grain, deep litter or milling.

The higher proportion of precipitins present in non-smokers and ex-smokers is statistically significant but not explained. There seems to be no comparable association between smoking and pneumoconiosis due to inert particles. In a study of coalworkers' pneumoconiosis Ashford et al. (1961) 
TABLE 5

Occupation and Serological Results by SeX

\begin{tabular}{|c|c|c|c|c|c|c|c|c|c|c|c|c|c|}
\hline \multicolumn{9}{|c|}{ Question } & \multirow{2}{*}{$\begin{array}{l} \\
\text { No } \\
\text { Yes }\end{array}$} & \multirow{2}{*}{$\begin{array}{c}\begin{array}{c}\text { Serological } \\
\text { results }\end{array} \\
\text { - ve } \\
+ \text { ve } \\
\text { - ve } \\
\text { + ve }\end{array}$} & \multirow{2}{*}{$\begin{array}{c}\text { Men } \\
4 \\
0,2 \\
85 \\
16,18\end{array}$} & \multirow{2}{*}{$\begin{array}{c}\text { Women } \\
24 \\
1,1 \\
25 \\
2,2\end{array}$} & \multirow{2}{*}{$\begin{array}{r}\text { Total } \\
28 \\
4 \\
110 \\
38\end{array}$} \\
\hline Farmwork full time & . & . & . & . & . & . & . & . & & & & & \\
\hline Farmwork part time & . & . & . & . & . & . & . & . & $\begin{array}{l}\text { No } \\
\text { Yes }\end{array}$ & $\begin{array}{l}-v e \\
+v e \\
-v e \\
+v e\end{array}$ & $\begin{array}{c}0 \\
0,0 \\
4 \\
0,2\end{array}$ & $\begin{array}{c}9 \\
0 \\
15 \\
1,1\end{array}$ & $\begin{array}{r}9 \\
0 \\
19 \\
4\end{array}$ \\
\hline $\begin{array}{l}\text { Exposed to dust from } \\
\text { (1) hay }\end{array}$ & 1: & . & . & . & $\cdots$ & . & . & . & $\begin{array}{l}\text { No } \\
\text { Yes }\end{array}$ & $\begin{array}{l}-v e \\
+v e \\
-v e \\
+v e\end{array}$ & $\begin{array}{c}2 \\
0,0 \\
87 \\
16,20\end{array}$ & $\begin{array}{c}3 \\
0,0 \\
46 \\
3,3\end{array}$ & $\begin{array}{r}5 \\
0 \\
133 \\
42\end{array}$ \\
\hline (2) grain & . & .. & . & . & . & $\cdots$ & . & . & $\begin{array}{l}\text { No } \\
\text { Yes }\end{array}$ & $\begin{array}{l}-v e \\
+v e \\
-v e \\
+v e\end{array}$ & $\begin{array}{c}35 \\
6,10 \\
54 \\
10,10\end{array}$ & $\begin{array}{c}42 \\
3,2 \\
7 \\
0,1\end{array}$ & $\begin{array}{l}77 \\
21 \\
61 \\
21\end{array}$ \\
\hline (3) milling & . & . & . & . & . & . & . & . & $\begin{array}{l}\text { No } \\
\text { Yes }\end{array}$ & $\begin{array}{l}-v e \\
+v e \\
-v e \\
+v e\end{array}$ & $\begin{array}{c}49 \\
9,12 \\
40 \\
7,8\end{array}$ & $\begin{array}{c}47 \\
3,2 \\
2 \\
0,1\end{array}$ & $\begin{array}{l}96 \\
26 \\
42 \\
16\end{array}$ \\
\hline (4) deep litter & $\cdots$ & . & . & - & $\cdots$ & . & .. & . & $\begin{array}{l}\text { No } \\
\text { Yes }\end{array}$ & $\begin{array}{l}\text {-ve } \\
+ \text { te } \\
\text { - ve } \\
+v e\end{array}$ & $\begin{array}{c}72 \\
13,11 \\
17 \\
3,9\end{array}$ & $\begin{array}{l}33 \\
1,2 \\
16 \\
2,1\end{array}$ & $\begin{array}{r}105 \\
27 \\
33 \\
15\end{array}$ \\
\hline Wears mask at any ti & ime & ring & prk & - & $\cdots$ & . & .. & . & $\begin{array}{l}\text { No } \\
\text { Yes }\end{array}$ & $\begin{array}{l}-v e \\
+v e \\
-v e \\
+v e\end{array}$ & $\begin{array}{c}64 \\
9,12 \\
25 \\
7,8\end{array}$ & $\begin{array}{c}46 \\
3,2 \\
3 \\
0,1\end{array}$ & $\begin{array}{r}110 \\
26 \\
28 \\
16\end{array}$ \\
\hline
\end{tabular}

Positive serological results recorded as $n_{1}$ and $n_{2}$ where $n_{1}$ is the number of weak positive results and $n_{2}$ the number of moderate and strong positive results.

found no consistent differences between the prevalence of pneumoconiosis among smokers, nonsmokers, and ex-smokers. Davies (1971) found that the proportion of men with pneumoconiosis among foundry workers appeared to increase with the amount smoked. It is possible that smoking prevents sensitization by $M$. faeni through a direct action on the spores.

Only one serological result showed a positive reaction to $T$. vulgaris and one to $A$. fumigatus and both were also positive for precipitins to $M$. faeni. There were no obvious clinical associations with positive precipitin reactions to the two former antigens. Hapke et al. (1968) reported a similar small proportion of positive reactions to these antigens in farmer's lung patients.

The proportion of positive serological reactions among random samples of farmers appears to show considerable variation between surveys. Apparent differences may be explained partly by differences in the techniques used for detecting precipitins. Five of the 10 people interviewed who reported attacks of breathlessness associated with fever and shivering were from the group of six known cases of farmer's lung, and we believe that others who reported such attacks were also suffering from this disorder despite negative precipitin tests. Apart from this group no definite relationship was found between chest symptoms, chest illness, and serological reactions. No clear differentiation in terms of past or present symptoms could be made between those with positive and those with negative precipitin tests. However, a larger study might provide such evidence and a further survey linked with similar studies in west Wales is now in progress.

We are indebted to Dr. R. Essame, Dr. T. Glanvill, and Dr. W. McBay for help in the conduct of the survey 
and in obtaining the sample for study from their practice lists. We are grateful for the advice and assistance provided by Dr. Brendan Moore, Dr. E. Hapke, Dr. G. O. Thomas, and Dr. J. Gilson and his colleagues of the Medical Research Council Pneumoconiosis Unit. Expenses were covered in part by grants from the Medical Research Council and the South Western Regional Hospital Board.

\section{References}

Ashford, J. R., Brown, S., Duffield, D. P., Smith, C. S., and Fay, J. W. J. (1961). The relation between smoking habits and physique, respiratory symptoms, ventilatory function, and radiological pneumoconioses amongst coal workers at three Scottish colleries. British Journal of Preventive and Social Medicine, 15, 106-117.

Boyd, D. H. A. (1971). The incidence of farmer's lung in Caithness. Scottish Medical Journal, 16, 261-262.

Campbell, J. M. (1932). Acute symptoms following work with hay. British Medical Journal, 2, 1143-1144.

Davies, T. A. Lloyd (1971). Respiratory Disease in Foundrymen: a Report of a Survey. Department of Employment. H.M.S.O., London.

Fletcher, C. M., Elmes, P. C., Fairbairn, A. S., and Wood, C. H. (1959). The significance of respiratory symptoms and the diagnosis of chronic bronchitis in a working population. British Medical Journal, 2, 257-266.

Fuller, C. J. (1953). Farmer's lung: a review of present knowledge. Thorax, 8, 59-64.

Grant, I. W. B., Blyth, W., Wardrop, V. E., Gordon, R. M., Pearson, J. C. G., and Mair, A. (1972). Prevalence of farmer's lung in Scotland: a pilot survey. British Medical Journal, 1, 530-534.

Hapke, E. J., Seal, R. M. E., and Thomas, G. O. (1968). Farmer's lung. Thorax, 23, 451-468.

Higgins, I. T. T. (1957). Respiratory symptoms, bronchitis, and ventilatory capacity in random sample of an agricultural population. British Medical Journal, 2, 1198-1203.

, and Cochran, J. B. (1958). Respiratory symptoms, bronchitis and disability in a random sample of an agricultural community in Dumfriesshire. Tubercle, 39, 296-301.

Medical Research Council (1966). Questionnaire on respiratory symptoms. M.R.C., London.

Olsen, H. C., and Gilson, J. C. (1960). Respiratory symptoms, bronchitis, and ventilatory capacity in men. British Medical Journal, 1, 450-456.

Pepys, J., and Jenkins, P. A. (1965). Precipitin (F.L.H.) test in farmer's lung. Thorax, 20, 21-35.

- _ Festenstein, G. N., Gregory, P. H., Lacey, M. E., and Skinner, F. A. (1963). Farmer's lung: thermophilic actinomycetes as a source of 'farmer's lung hay' antigen. Lancet, 2, 607-611.

- Longbottom, J. L., and Jenkins, P. A. (1964). Vegetable dust pneumoconioses. American Review of Respiratory Disease, 89, 842-858.

Tobacco Research Council (1972). Statistics of Smoking in the United Kingdom, edited by G. F. Todd. Research Paper No. 1, 6th ed. Tobacco Research Council, London.

Wenzel, F. J., Gray, R. L., and Emanuel, D. A. (1970). Farmer's lung. Its geographic distribution. Journal of Occupational Medicine, 12, 493-496.

Received for publication August 31, 1972.

Accepted for publication January 23, 1973. 